\title{
PENGARUH RAGAM KONSELI SUKARELA TERHADAP KEBERHASILAN PENINGKATAN MUTU AKADEMIK PESERTA DIDIK SMP MA'ARIF 5 KOTA METRO
}

\author{
Andika Ari Saputra, Rizky Hidayatullah, Muhyidin Thohir \\ IAIM NU Metro Lampung \\ ari.andika75@gmail.com, ari.andika75@yahoo.com,rizky.hidayatullah17@gmail.com
}

\begin{abstract}
ABSTRAK
Penelitian ini bertujuan untuk mengetahui pengaruh ragam konseli sukarela dalam pemberian layanan bimbingan dan konseling oleh guru bimbingan dan konseling terhadap peningkatan mutu akademik peserta didik SMP Ma'arif 5 Kota Metro. Pemberian layanan bimbingan dan konseling kepada peserta didik diharapakan dapat memandirikan peserta didik dan memiliki sikap kesukarelaan dalam mengikuti pelayanan bimbingan dan konseling, sehingga dapat meningkatkan mutu akademik atau prestasi. Metode penelitian ini menggunakan survey dengan prosedur untuk memecahkan suatu penelitian. Penelitian adalah kegiatan ilmiah yang dilaksanakan melalui metode penelitian dapat diartikan juga sebagai cara untuk mengungkapkan gejala alam, sosial dalam kehidupan yang terjadi pada individu, serta dapat mempergunakan prosedur kerja sistematis, teratur, tertib, dan dapat dipertanggungjawabkan dengan secara ilmiah. Hasil penelitian menunjukkan bahwa pemberian layanan bimbingan dan konseling dalam rangka peningkatan mutu akademik di sekolah sangat berpengaruh terhadap keaktifan dan kesukarelaan peserta didik agar mandiri dalam belajar. Mutu akademik di sekolah sangat mempengaruhi kualitas belajar peserta didik dan profesional guru dalam mengajar.
\end{abstract}

Kata kunci : konseli sukarela, mutu akademik, peserta didik SMP

\section{THE EFFECT OF VARIETY OF VOLUNTEER COUNSELS ON THE SUCCESS OF IMPROVING THE ACADEMIC QUALITY OF STUDENTS OF SMP MA'ARIF 5 KOTA METRO}

\begin{abstract}
This study aims to determine the effect of various voluntary counselees in providing guidance and counseling services by guidance and counseling teachers on improving the academic quality of students of SMP Ma'arif 5 Metro City. It is hoped that the provision of guidance and counseling services to students can make students independent and have a voluntary attitude in participating in guidance and counseling services, so as to improve academic quality or achievement. This research method uses a survey with procedures to solve a study. Research is a scientific activity carried out through research methods which can be interpreted as a way to reveal natural, social phenomena in life that occur in individuals, and can use systematic, orderly, orderly work procedures and can be scientifically accounted for. The results showed that the provision of guidance and counseling services in order to improve academic quality in schools greatly influenced the activeness and volunteerism of students to be independent in learning. Academic quality in schools greatly affects the quality of learning of students and professional teachers in teaching.
\end{abstract}

Keywords : voluntary counselee, academic quality, junior high school students 


\section{Pendahuluan}

Permasalahan yang dihadapi peserta didik tampaknya semakin lama semakin komplek, baik permasalahan yang berhubungan dengan pribadi, keluarga, maupun lingkungan sekolah. Kompleksitas masalah yang demikian inilah yang menuntut peserta didik dapat mandiri dalam menyelesaikan dan mengatasi segenap permasalahan yang dapat mengganggu kelancaran studi peserta didik. Menyelesaikan masalah peserta didik bukan hanya sebatas mendengarkan, namun untuk mengarahkan, menerima segala keluh-kesah yang ada pada pikiraan serta perasaan peserta didik. Namun dapat membantu menyelesaikan masalah peserta didik, membutuhkan berbagai cara untuk mengetahui masalah yang sebenarnya. Agar peserta didik yang bermasalah mampur mengungkapkan sesuatu yang tersembunyi di bawah kesadaran diri, di bawah kemampuan diri, maka peserta didik membutuhkan tempat untuk membantunya mengatasi permasalahan yang mengganggu kehidupannya baik masalah belajar, keluarga, sosial (Prayitno, 2004).

Konseling merupakan pemberian layanan yang dilakukan melalui wawancara konseling oleh seorang konselor kepada peserta didik yang sedang mengalami sesuatu masalah agar teratasi masalah yang dihadapi konseli(Prayitno, 2004). Peranan guru bimbingan dan konseling dalam mengusahakan keberhasilan proses konseling sangat diperlukan (Latipun, 2001). Keberhasilan proses konseling dapat dilihat dari proses dan kegiatan layanan yang diberikan kepada konseli oleh konselor, apakah permasalahannya telah terungkap. Keberhasilan sebuah proses konseling juga ditentukan ketika seorang konselor mampu melibatkan konseli secara penuh, supaya konseli bisa dengan sukarela datang dan dengan sukarela pula terlibat dalam proses konseling.

Konseling merupakan individu yang memiliki kekuatan dan motivasi, memiliki kemauan untuk berubah, dan pelaku bagi perubahan dirinya (Latipun, 2001). Motivasi peserta didik (konseli) untuk datang pada konselor yang didasari atas kesadaran bahwa peserta didik (konseli) punya masalah dan membutuhkan orang lain (konselor) menjadi syarat keberhasilan konseling. Motivasi peserta didik untuk berubah inilah yang akan mendasarinya secara sukarela untuk datang kepada konselor dalam rangka penyelesian masalah melalui proses konseling. Hal ini didukung dengan penelitian yang menjelaskan pengaruh yang sangat signifikan antara motivasi konseli dengan keberhasilan konseling. Berdasarkan pemaparan di atas maka konseli sukarela (yang didasari pemahaman diri dan motivasi) akan menunjang tercapainya keberhasilan peningkatan mutu akademik pada peserta didik di sekolah (Alfiatu, 
2014).

Keberadaan pemberian layanan bimbingan dan konseling serta bimbingan dan konseling islam sudah sangat terasa dibutuhkan di sekolah. Hal ini dibuktikan dengan diberikannya kesempatan dari kepala sekolah kepada guru bimbingan dan konseling untuk memberikan jenis layanan bimbingan dan konseling kepada peserta didik. Jenis layanan yang diberikan dapat melatih agar peserta didik mandiri dan sukarela dalam mengikuti kegiatan atau layanan bimbingan dan koneling yang ada di sekolah. Peneliti melakukan studi awal di lapangan dan juga didampingi oleh mahasiswa pada tanggal 14 Desember 2019 didapatkan suatu pengalaman yang menarik. Hasil observasi dan wawancara dengan guru bimbingan dan konseling, yaitu pada kenyataannya seperti yang terjadi di SMP Ma'arif 5 Kota Metro, guru bimbingan dan konseling telah memberikan layanan secara maksimal, namun masih ada sebagian peserta didik belum mandiri dan belum memiliki sikap kesukarelaan untuk datang berkonsultasi atau bimbingan dengan guru bimbingan dan konseling di sekolah.

Jenis layanan bimbingan dan konseling serta bimbingan dan konseling islam yang diberikan oleh guru bimbingan dan konseling dapat membantu memecahkan masalah belajar ataupun mengembangkan potensi akademik peserta didik. Mutu akademik merupakan salah satu wujud keunggulan yang berfokus pada keberhasilan peserta didik. Mutu akademik menunjukkan ukuran penilaian serta penghargaan yang diberikan peserta didik berdasarkan pertimbangan objektif. Sekolah dan madrasah harus mampu menjawab kebutuhan dan harapan peserta didiknya. Sekolah dan madrasah yang dapat meningkatkan mutu akademik yang baik bagi peserta didik merupakan sekolah yang unggul memiliki iklim belajar yang baik sehingga dapat meningkatkan mutu pembelajaran (Alfiatu, 2014). Maka perilaku konseli juga sangat menenentukan keberhasilan peningkatan mutu akademik pada peserta didik. Berdasarkan latar belakang di atas, maka peneliti tertarik untuk mengkaji lebih dalam melalui sebuah penelitian dengan judul "Pengaruh Ragam Konseli Sukarela Terhadap Keberhasilan Peningkatan Mutu Akademik”.

Fokus masalah dalam penelitian ini adalah sebagai berikut, "sebagian peserta didik belum memiliki kesukarelaan dalam mengikuti pelayanan bimbingan dan konseling yang diberikan oleh guru sehingga berpengaruh terhadap keberhasilan peningkatan mutu akademik". Berdasarkan latar belakang masalah yang dipaparkan, rumusan masalah dalam penelitian ini, sebagai berikut, "apakah ragam konseli sukarela berpengaruh terhadap keberhasilan peningkatan mutu akademik peserta didik". Tujuan dari penelitian ini adalah 
untuk menganalisis pengaruh ragam konseli sukarela terhadap keberhasilan peningkatan mutu akademik pada peserta didik dan memberi gambaran bagaimana keberhasilan peningkatan mutu akademik pada peserta didik dipengaruhi oleh ragam konseli sukarela. Apabila terdapat pengaruh maka penelitian ini dapat dijadikan dasar untuk penelitian selanjutnya. Penelitian ini memiliki manfaat serta berkontribusi untuk mengetahui upayaupaya sekolah terutama guru bimbingan dan konseling di SMP Ma'arif 5 Kota Metro dalam meningkatkan keberhasilan mutu akademik peserta didik, serta berkontribusi untuk meningkatkan pemahaman sekolah terhadap pentingnya ragam konseling sukarela yang dilakukan oleh peserta didik.

Pada akhirnya motivasi peserta didik untuk berubah akan mendasarinya secara sukarela untuk datang kepada konselor dalam rangka penyelesian masalah melalui proses konseling. Hal ini didukung dengan penelitian bahwa terdapat pengaruh signifikan antara motivasi konseli dengan keberhasilan konseling (Mudjijanti, 2012). Motivasi dalam diri peserta didik (konseli) membantu menyesuaikan antara harapan-harapan yang ingin dicapai dengan realita, serta dapat membantu menghadapi kegagalan yang mungkin akan terjadi dengan realistis (Surya, 1988).

Konseli merupakan semua peserta didik yang diberikan bantuan secara profesional oleh seorang konselor atas permintaan konseli atau atas permintaan orang lain (Willis, 2004). Konseli merupakan subjek yang memiliki kekuatan, motivasi, memiliki kemauan untuk berubah, dan pelaku bagi perubahan dirinya sendiri. Proses konseling kiranya perlu pula untuk memahami aneka ragam peserta didik (konseli). Jika seorang konseli datang kepada konselor tentunya memiliki maksud yang terkandung di dalam hatinya. Namun banyak pula konseli yang datang tanpa maksud yang jelas atau mungkin pula kehadirannya karena terpaksa oleh ajakan atau suruhan orang. Konseli sukarela merupakan konseli yang hadir di dalam ruang konseling atas kesadaran sendiri yang berhubung ada maksud dan tujuannya.

Bimbingan dan konseling merupakan terjemahan dari "guidance" dan "counseling” dalam bahasa Inggris secara harfiah istilah guidance dari akar kata guide berarti mengarahkan (to direct) memandu (to pilot), mengelola (to manage), menyetir (to steer). Hal ini dapat kita lihat dalam firman Allah surat Al-kahfi : 10, yang artinya: “(ingatlah) tatkala para pemuda itu mencari tempat berlindung ke dalam gua, lalu mereka berdoa: "Wahai Tuhan Kami, berikanlah rahmat kepada kami dari sisi-mu dan sempurnakanlah bagi kami petunjuk yang lurus dalam urusan kami ini (QS. Al-kahfi: 10). 
Fungsi bimbingan dan konseling dapat ditunjukkan kepada peserta didik yang mengalami persoalan yang serius, maka dapat dikatakan bahwa bimbingan dan konseling sangat menunjang perkembangan peserta didik secara optimal, terutama dalam proses belajar mengajar. Bimbingan dan konseling tidak hanya sebagai pengiring dalam proses pendidikan dan pengajaran, tetapi merupakan bagian integral dari pendidikan dalam lingkup sekolah. Pelaksanaan bimbingan dan konseling yang merupakan bagian integral dari proses pendidikan, terdapat 3 fungsi utama, yaitu penyaluran (distribitive), pengadaptasian (adaptive), penyesuaian (adjustive) (Gudnanto, 2015).

Pemberian pelayanan bimbingan dan konseling di sekolah dan madrasah dari tingkat satuan pendidikan di sekolah dasar hingga perguruan tinggi, dewasa ini saling dibutuhkan. Seiring dengan adanya perkembangan ilmu pengetahuan dan teknologi (IPTEK), berbagai persoalanpun muncul dengan segala kompleksitasnya. Dunia penidikan tampaknya belum sepenuhnya mampu menjawab berbagai persoalan akibat perkembangan IPTEK, indikasinya adalah munculnya berbagai penyimpangan perilaku di kalangan peseta didik yang seyogiyanya tidak di lalukukan oleh seorang atau orang yang di sebut terdidik.

Selain itu, potensi peserta didik sebagai individu memiliki bakat, minat, cita-cita, dan lain sebagainya juga belum berkembang dan tersalurkan secara optimal melalui proses pendidikan dan pembelajaran di kelas. Guna memecahkan persoalan-persoalan di atas, proses pendidikan dan pembelajaran perlu di sinergi dengan pemberian pelayanan bimbingan dan konseling. Optimalisasi pelayanan bimbingan dan konseling di sekolah dan madrasah dapat memberikan kontribusi pada pencapaian visi, misi, dan tujuan sekolah dan madrasah yang bersangkutan.

Peran utama konselor dalam konseling dengan pendekatan ini adalah sebagai "pengingat". Yaitu sebagai orang yang mengingatkan individu yang dibimbing dengan cara Allah. Dikatakan mengingatkan sebab (a) pada dasarnya individu telah memiliki iman, jika iman yang ada pada individu tidak tumbuh diduga individu lupa merawatnya, lupa memberi pupuknya, atau diserang penyakit; akibatnya iman itu tidak tumbuh dan tidak berfungsi dengan baik. (b) Allah telah mengutus rasul-Nya dengan membawa Kitab Suci sebagai pedoman hidup, jika ada individu yang mengalami kebingungan atau salah jalandiduga mereka belum memahami petunjuk.

Peserta didik yang salah penyesuaian perlu memperoleh bantuan agar perkembangan kepribadiannya berlangsung secara baik. Konseling pada prinsipnya antara lain berusaha 
membantu peserta didik mengubah perilkau yang salah penyesuaian menjadi berperilaku yang tepat didalam penyesuaiannya. Keberhasilan layanan konseling yang telah diberikan kepada peserta didik dapat dilihat dari perubahan tingkah laku atau sikap peserta didik yang telah mendapatkan pelayanan. Diharapkan setelah menerima konseling maka peserta didik mandiri dan mengetahui cara belajar yang tepat, sehingga mampu meningkatkan mutu akademiknya (Partowisastro, 1982).

Peningkatan mutu akademik pada peserta didik di sekolah dapat diupayakan melalui berbagai kegiatan pembelajaran, seminar, pendidikan pelatihan ataupun workshop, serta layanan konseling. Melalui berbagai kegiatan tersebut dikenalkan pada inovasi-inovasi pembelajaran, karena inovasi adalah sebagai suatu kebutuhan. Pengembangan bahan ajar, pengembangan strategi dan metode pembelajaran, pengembangan media pembelajaran, sistem penilaian, evaluasi, dan asesmen telah menjadi menu utama dunia pendidikan, namun dari pengalaman empirik tampaknya pada upaya-upaya perlu didukung secara signifikan dengan memberikan layanan konseling oleh konselor terhadap peserta didik untuk membawa perubahan dalam arti peningkatan mutu akademik pada peserta didik di sekolah (Moh. Saifulloh, Zainul Muhibbin dan Hermanto, 2012).

Meningkatnya mutu akademik peserta didik di sekolah sangat mempengaruhi kualitas belajar dan profesional guru dalam mengajar. Peningkatan mutu akademik peserta didik di sekolah juga diperlukan adanya peran khusus dari guru bimbingan dan konseling atau konselor upaya memperbaiki kualitas pendidikan. Pemberian layanan konseling yang dilakukan oleh konselor kepada peserta didik mempengaruhi prestasi belajar, terlebih peserta didik yang dengan sukarela datang ke ruang konseling dan mendapatkan layanan secara maksimal.

Konseling merupakan proses untuk membantu peserta didik mengatasi hambatanhambatan perkembangan dirinya, serta untuk mencapai perkembangan secara optimal pada kemampuan pribadi yang dimilikinya, proses tersebut dapat terjadi setiap waktu (Prayitno, 2004). Proses layanan konseling dapat meliputi pemahaman dan hubungan peserta didik untuk mengungkapkan yang berkitan dengan kebutuhan-kebutuhan, motivasi, dan potensipotensi dari peserta didik dan membantu peserta didik yang bersangkutan untuk mengapresiasikan.

Pada akhirnya motivasi yang dilakukan peserta didik untuk berubah akan mendasarinya secara sukarela untuk datang kepada konselor dalam rangka penyelesian masalah melalui 
proses konseling. Hal ini didukung dengan penelitian bahwa terdapat pengaruh signifikan antara motivasi konseli dengan keberhasilan konseling (Mudjijanti, 2012). Motivasi dalam diri konseli dapat membantu menyesuaikan antara harapan-harapan yang akan dicapai dengan realita yang ada, serta membantu menghadapi kegagalan yang mungkin akan terjadi dengan realistis (Surya, 1988).

Peningkatan mutu akademik pada peserta didik di sekolah dapat diupayakan melalui berbagai kegiatan pembelajaran, seminar, pendidikan pelatihan ataupun workshop, serta layanan konseling. Melalui berbagai kegiatan tersebut dikenalkan pada inovasi-inovasi pembelajaran, karena inovasi adalah sebagai suatu kebutuhan. Pengembangan bahan ajar, pengembangan strategi dan metode pembelajaran, pengembangan media pembelajaran, sistem penilaian, evaluasi, dan asesmen telah menjadi menu utama dunia pendidikan, namun dari pengalaman empirik tampaknya pada upaya-upaya perlu didukung secara signifikan dengan memberikan layanan konseling oleh konselor kepada peserta didik untuk membawa perubahan dalam arti peningkatan mutu akademik pada peserta didik di sekolah (Moh. Saifulloh, 2012).

Pemahaman diri peserta didik terhadap masalah yang dialaminya membutuhkan bantuan untuk memecahkan masalah tersebut, karena pada dasarnya peserta didik bisa memilih, merefleksikan, dan memutuskan segala sesuatu dalam kehidupan, terutama dalam lingkungan belajar. Adanya kesadaran dan pemahaman peserta didik akan menjadi bebas untuk menentukan apa saja yang akan membuatnya bahagia dan cenderung memiliki sikap sukarela untuk datang kepada konselor dalam rangka pemecahan masalahnya, terutama berkaitan dengan proses belajar di sekolah.

\section{Metode Penelitian}

Jenis penelitian yang digunakan adalah jenis penelitian kualitatif. Desain kualitatif memberikan kesempatan bagi peneliti untuk melihat keadaan yang sebenarnya ada di lapangan serta pengaruh yang ada di variable penelitian. Metode penelitian ini menggunakan survey dengan prosedur untuk memecahkan suatu penelitian. Penelitian adalah kegiatan ilmiah yang dilaksanakan melalui metode penelitian dapat diartikan juga sebagai cara untuk mengungkapkan gejala alam, sosial dalam kehidupan yang terjadi pada individu, serta dapat mempergunakan prosedur kerja sistematis, teratur, tertib, dan dapat dipertanggungjawabkan dengan secara ilmiah (Nawawi \& Hadari, 1991). 
Peneliti menggunakan instrumen wawancara dan dokumentasi untuk menunjang keberhasil dalam penelitian ini. Pentingnya metode dalam penelitian yaitu prosedur dan cara melakukan verifikasi dan data diperlukan untuk memecahkan atau menjawab masalah penelitian (Sudjana, 1991). Teknik atau cara pengumpulan data dalam penelitian ini menggunakan observasi dan wawancara dengan guru bimbingan dan konseling. Pengumpulan data dilakukan dengan mengadakan observasi dan wawancara dengan guru bimbingan dan konseling. Observasi dan wawancara juga meliputi stake holder yang ada di SMP Ma'arif 5 Kota Metro.

\section{Hasil dan Pembahasan}

SMP Ma'arif 05 diririkan oleh Lembaga Pendidikan Ma'arif kabupaten Lampung Tengah, pada tanggal 1 Juli 1988 dengan akte notaris no. 07 tahun 1972 oleh PPAT (Joenoes Mugimon, S.H) di Jakarta tanggal 15 Maret 1972 dengan izin operasional dari mendikbud no. 103/I/986 tentang persetujuan untuk mendirikan sekolah swatas dasar pendidikan SMP Ma'arif 05 kota Metro sebagai berikut, sebagai amal usaha Lembaga Pendidikan Ma'arif NU yang nyata dalam prestasi membantu program pemerintah di bidang pendidikan, masih terbatasnya SMP Ma'arif 05 kota Metro di Metro sedangkan lulusan SD setiap tahun bertambah, amanat departemen pendidikan dan kebudayaan dalam rangka mencerdaskan kehidupan bangsa. Paparan data hasil dalam penelitian ini, akan menggambarkan data mengenai : (1) Perumusan strategi yang terdiri dari atas perumusan visi, misi sekolah, kemudian analisis kekuatan, kelemahan, dan peluang yang memperhatikan faktor dari dalam dan luar pemberian layanan bimbingan dan konseling kepada peserta didik sehingga menghasilkan tujuan dan strategi yang akan digunakan untuk meningkatkan mutu akademik.

Hasil penelitian menunjukkan perumusan dan perencanaan strategi pemberian layanan bimbingan dan konseling disusun melalui program untuk mempersiapkan masa depan SMP Ma'arif 5 Kota Metro. Perencanaan merupakan salah satu kegiatan manajerial dalam mengelola sebuah organisasi, khususnya dalam bidang pendidikan. Perencanaan dalam fungsi manajemen pemberian layanan bimbingan dan konseling adalah proses pengambilan keputusan mendasar tentang kegiatan yang akan dilaksanakan untuk mencapai tujuan. Dalam hal ini, perencanaan pemberian layanan bimbingan dan konseling merupakan salah satu langkah awal dalam proses manajemen strategik dalam 
meningkatkan mutu akademik peserta didik di lembaga pendidikan SMP Ma'arif 5 Kota Metro. (2) Implementasi strategi pemberian layanan bimbingan dan konseling kepada peserta didik terdapat program tahunan yang telah ditetapkan, mengembangkan layanan informasi yang mendukung kemajuan peserta didik dalam belajar.

Hasil penelitian menunjukkan implementasi strategi pemberian layanan bimbingan dan konseling tepat sasaran kepada seluruh peserta didik yang ada di SMP Ma'arif 5 Kota Metro. Didapatkan hasil penelitian yang menarik bahwa ada sebagian peserta didik yang belum memiliki sikap kesukarelaan dalam mengikuti kegiatan atau pemberian layanan bimbingan dan konseling, yang dapat berakibat pada penurunan mutu akademik di sekolah tersebut. Pemberian layanan bimbingan dan konseling sudah tetap sasaran namun masih ada peserta didik yang tidak disiplin bahkan melanggar peraturan yang ada di sekolah. (3) Evaluasi strategi pemberian layanan bimbingan dan konseling kepada peserta didik terdiri atas langkah-langkah kepala sekolah dan guru bimbingan dan konseling melakukan evaluasi terhadap program-program yang telah dilaksanakan.

Hasil penelitian menunjukkan pengamatan dan penilaian terhadap lingkungan sekolah terutama evaluasi strategi pemberian layanan bimbingan dan konseling kepada peserta didik dapat membantu kepala sekolah dan guru bimbingan dan konseling dalam menemukan kekukatan dan kelemahan yang dimiliki sekolah serta ancaman dan peluang yang mungkin timbul. Dalam melakukan analisis tersebut, dibutuhkan kecermatan dalam melakukan pengamatan terhadap pemberian layanan bimbingan dan konseling kepada peserta didik. Melalui hasil analisis yang dilakukan peneliti juga membantu kepala sekolah dan guru bimbingan dan konseling mengenal lebih jauh programprogram dan pencapaian prestasi untuk peningkatan mutu akademik peserta didik di SMP Ma'arif 5 Kota Metro.

Pelaksanaan pelayanan bimbingan dan konseling merupakan kegiatan yang bersumber pada kehidupan manusia. Kenyataan menunjukkan bahwa manusia di dalam kehidupan sering menghadapi persoalan-persoalan yang silih berganti. Hal ini juga terjadi pada peserta didik SMP Ma'arif 05 Kota Metro yang mana dalam pelaksanaan pelayanan bimbingan dan konseling yang diberikan guru untuk menangani peserta didik yang sedang memiliki masalah baik pribadi maupun pelajaran.

Adapun pemberian layanan bimbingan dan konseling oleh guru memiliki pengaruh ragam konseli sukarela (layanan bimbingan konseling dan bimbingan konseling islam) 
terhadap keberhasilan peningkatan mutu akademik peserta didik SMP Ma'arif 5 Kota Metro, dibuktikan dengan adanya perubahan sikap dan perilaku peserta didik menjadi lebih terarah dan mandiri. Berdasarkan hasil wawancara dengan kepala sekolah dan guru bimbingan dan konseling didapatkan masih banyak peserta didik yang masih belum memiliki kesukarelaan dalam mengikuti kegiatan atau pemberian layanan bimbingan dan koseling, yang berakibat pada kemandirian peserta didik yang rendah dalam belajar.

Namun ada sebagian peserta didik yang memiliki kesukarelaan dalam mengikuti kegiatan atau pemberian layanan bimbingan dan konseling, didapatkan perubahan perilaku yang signifikan terhadap peningkatan mutu akademik peserta didik tersebut. Perubahan meliputi kemandirian dalam belajar, peningkatan hasil belajar, serta adanya perilaku untuk menuju perubahan diri yang lebih baik.

\section{Kesimpulan}

Mutu akademik SMP Ma'arif 5 Kota Metro dilihat dari kompetensi tenaga kependidikan sudah memenuhi kompetensi standar, namun ada beberapa catatan untuk guru bimbingan dan konseling yang masih belum linier dengan program studi yang ditetapkan. Hal tersebut dapat dilihat dari kualifikasi akademik dan standar kompetensi tenaga kependidikan yang belum sesuai dengan bidang pekerjaannya. Bahkan tenaga kependidikan tersebut juga merangkap sebagai tenaga pendidik sehingga pekerjaan yang menjadi tanggungannya tidak bisa di kerjakan secara efektif dan maksimal.

Pemberian layanan bimbingan dan konseling oleh guru bimbingan dan konseling dapat menuju pada perencanaan, pengorganisasian, penggerakan dan pengawasan dalam upaya peningkatan mutu akademik pada peserta didik SMP Ma'arif 5 Kota Metro. Dari upayaupaya pemberian layanan bimbingan dan konseling yang dilakukan oleh guru bimbingan dan konseling dapat diketahui hasilnya bahwa peserta didik yang dengan sukarela mengikuti kegiatan atau layanan bimbingan dan konseling dapat berpengaruh untuk meningkatkan mutu akademik peserta didik di sekolah.

Berdasarkan dari kompetensi tenaga kependidikan, kepada kepala sekolah disarankan agar merekrut tenaga kependidikan yang baru yang mempunyai kompetensi sesuai dengan bidang pekerjaannya agar tenaga pendidik tidak merangkap pekerjaan sebagai tenaga kependidikan sehingga karyawan dan guru mampu bekerja secara efektif dan maksimal. Kepada tenaga pendidik terutama guru bimbingan dan konseling disarankan agar 
selalu meningkatkan kompetensi personal, artinya kompetensi setiap personil selalu di tingkatkan agar mampu memberikan layanan bimbingan dan konseling dengan baik dan maksimal untuk kemajuan di sekolah.

\section{Daftar Pustaka}

Alfiatu, S. Strategi Peningkatan Mutu Pembelajaran Pada Sekolah Unggulan. Didaktika Religia Volume 2, No. 1, hal.175-212, 2014.

Al-Qur'an dan Terjemahnya, Khadim al Haramain asy-Syarifain Departemen Agama Republik Indonesia.

Gudnanto. Peran Bimbingan Dan Konseling Islami Untuk Mencetak Generasi Emas Indonesia. Jurnal Konseling GUSJIGANG. Vol. 1 No. 1, hal.1-11, 2015.

Latipun. Psikologi Konseling. Malang: UMM Press. 2001.

Moh. Saifulloh, Zainul Muhibbin dan Hermanto. Strategi Peningkatan Mutu Pendidikan Di Sekolah. JSH: Jurnal Sosial Humaniora, Vol 5 No.2, hal. 206-217, November 2012.

Mudjijanti, Fransisca. "Pengaruh Motivasi Konseli Dan Sikap Empati Konselor Terhadap Keberhasilan Proses Konseling." Widya Warta 36, 02, 2013.

Nawawi \& Hadari. Instrumen Penelitian Bidang Sosial. Yogyakarta : Gadjah Mada University Press. 1991.

Partowisastro, K. Bimbingan dan Penyuluhan di sekolah-sekolah. Jakarta : Erlangga. 1982.

Prayitno. Dasar-dasar Bimbingan dan Konseling. Jakarta: Rineka Cipta. 2004.

Sudjana. Desain dan Analisis Eksperimen. Bandung: Tarsito. 1991.

Sugiyono. Statistik Untuk Penelitian. Bandung : CV. Alfabeta. 2003.

Surya, M. Dasar-dasar Konseling Pendidikan (Konsep dan Teori). Yogyakarta: Kota Kembang. 1988.

Willis, S. Konseling Peserta didikal:Teori dan Praktek. Bandung:Alfabeta. 2004. 